\title{
Short communication: Effects of molasses supplementation on performance of lactating cows fed high-alfalfa silage diets
}

\author{
B. Baurhoo*1 and A. Mustafa ${ }^{1}$ \\ *Bélisle Solution \& Nutrition Inc., Saint-Mathias sur Richelieu, QC, J3L 6A7, Canada \\ †Department of Animal Science, McGill University, Ste-Anne-De-Bellevue, QC, H9X 3V9, Canada
}

\begin{abstract}
Twelve Holstein cows were used in a replicated Latin square experiment to determine the effect of adding dried molasses to high-alfalfa silage diets on dairy cow performance. Three isonitrogenous diets were formulated with a 68:32 forage:concentrate ratio, with alfalfa silage as the only forage source. Dietary treatments were a control diet with no added molasses and 3 and $6 \%$ dried molasses diets. Three lactating Holstein cows fitted with ruminal cannulas were used to determine the effects of dietary treatments on ruminal fermentation. Dietary treatments had no effect on dry matter (average $23.3 \mathrm{~kg} / \mathrm{d}$ ), crude protein (average $4.4 \mathrm{~kg} / \mathrm{d}$ ), or neutral detergent fiber (average $7.4 \mathrm{~kg} / \mathrm{d}$ ) intake. Milk yield, energy-corrected milk (average $35.4 \mathrm{~kg} / \mathrm{d}$ ), and $4 \%$ fat-corrected milk (average $33.8 \mathrm{~kg} / \mathrm{d}$ ) were not influenced by dietary treatments. Cows fed the control diet produced milk with less milk urea nitrogen concentration than those fed molasses-supplemented diets. Ruminal $\mathrm{pH}, \mathrm{NH}_{3}-\mathrm{N}$ concentration, and total volatile fatty acids were not different among dietary treatments. The molar proportion of acetate linearly increased, whereas the molar proportion of propionate linearly decreased as the level of dried molasses increased. It was concluded that addition of dried molasses to high-alfalfa silage diets at $6 \%$ of the diet (dry matter basis) increased milk urea nitrogen but had no effect on animal performance.
\end{abstract}

Key words: alfalfa silage, dairy cow, milk yield, molasses

\section{Short Communication}

Diets based on alfalfa silage contain high levels of NPN and other sources of rapidly ruminally degraded protein, which may reduce the efficiency of protein utilization by lactating cows (Broderick, 1995). When high-alfalfa silage diets are fed to lactating cows, the

\footnotetext{
Received May 2, 2013.

Accepted October 26, 2013.

${ }^{1}$ Corresponding authors: arif.mustafa@mcgill.ca and bbaurhoo@ belisle.net
}

rate of ruminal carbohydrate fermentation may be too slow to allow ruminal bacteria to capture readily available protein for microbial protein synthesis. Under these conditions, increasing the rate of carbohydrate fermentation could increase microbial protein synthesis and therefore improve the supply of MP to dairy cows (Broderick et al., 2002). Given that sugars are more rapidly fermented in the rumen than starch, these could serve as an effective supplement for high-alfalfa silage-based diets. Molasses in dry or liquid form is a practical source of rapidly fermented sugars for feeding dairy cows. Previous studies showed positive effects of added dry or liquid molasses on FCM, milk fat concentration, ruminal $\mathrm{NH}_{3}-\mathrm{N}, \mathrm{MUN}$, and fiber digestibility (Broderick and Radloff, 2004). Those authors recommended an optimum inclusion rate of $2.4 \%$ liquid or dried molasses to diets formulated with alfalfa and corn silages. However, feeding higher levels of molasses was found to reduce cow performance (Broderick and Radloff, 2004). Data regarding the effects of molasses inclusion in high-alfalfa silage diets on the performance of dairy cows are limited. The objectives of this study were to determine the effects of adding dried molasses to high-alfalfa silage-based diets on performance, ruminal fermentation, and total-tract nutrient utilization by lactating dairy cows.

Twelve multiparous cows in early to mid lactation $(702.8 \pm 77 \mathrm{~kg}$ of BW, $96.5 \pm 43$ DIM, and $39.9 \pm 4.62$ milk yield; average \pm SD) were blocked into 4 groups of 3 by parity and milk yield. Dietary treatments were a control diet without dried molasses and 3 and $6 \%$ dried molasses diets. Cows were housed in tie-stalls with free access to water. Three isonitrogenous diets were formulated, with a 68:32 forage:concentrate ratio to meet the nutrient requirements of dairy cows in early lactation (NRC 2001; Table 1). Diets were offered ad libitum twice daily at 0800 and $1600 \mathrm{~h}$. Experimental periods $(n=3)$ consisted of $14 \mathrm{~d}$ of diet adaptation and $7 \mathrm{~d}$ of data collection. Cows were milked 2 times daily at 0500 and $1700 \mathrm{~h}$, and milk yield and feed intake were recorded daily. Individual milk samples were collected 2 times per period. Diets were sampled daily and composited by period. Orts were measured daily to determine daily feed intake for each cow. 
Table 1. Ingredients and chemical composition $( \pm \mathrm{SD})$ of dietary treatments (DM basis)

\begin{tabular}{|c|c|c|c|}
\hline \multirow[b]{2}{*}{ Composition } & \multicolumn{3}{|c|}{ Dietary treatment } \\
\hline & $0 \%$ molasses & $3 \%$ molasses & $6 \%$ molasses \\
\hline Alfalfa silage & 68.4 & 68.2 & 68.2 \\
\hline High-moisture corn & 28.3 & 25.4 & 23.0 \\
\hline Dried molasses $^{1}$ & 0 & 2.8 & 5.6 \\
\hline Megalac $^{2}$ & 1.2 & 1.2 & 1.2 \\
\hline Mineral and vitamin $\operatorname{mix}^{3}$ & 2.1 & 2.1 & 2.1 \\
\hline \multicolumn{4}{|l|}{ Chemical composition, $\%$} \\
\hline DM & $45.2 \pm 1.33$ & $45.4 \pm 1.05$ & $45.6 \pm 0.95$ \\
\hline Ash & $7.8 \pm 0.91$ & $8.1 \pm 0.65$ & $8.5 \pm 0.60$ \\
\hline NDF & $31.5 \pm 1.04$ & $31.8 \pm 0.28$ & $31.9 \pm 0.41$ \\
\hline $\mathrm{ADF}$ & $22.1 \pm 1.38$ & $21.6 \pm 0.87$ & $22.6 \pm 0.74$ \\
\hline $\mathrm{CP}$ & $18.7 \pm 0.99$ & $18.9 \pm 0.20$ & $19.2 \pm 0.20$ \\
\hline Soluble protein, $\%$ of $\mathrm{CP}$ & $52.5 \pm 0.98$ & $55.4 \pm 0.82$ & $57.7 \pm 1.88$ \\
\hline NPN, $\%$ of CP & $52.3 \pm 0.81$ & $55.0 \pm 0.97$ & $55.4 \pm 0.40$ \\
\hline Neutral detergent-insoluble protein, $\%$ of CP & $13.9 \pm 1.34$ & $13.6 \pm 1.15$ & $12.8 \pm 1.02$ \\
\hline Acid detergent-insoluble protein, $\%$ of $\mathrm{CP}$ & $6.0 \pm 0.49$ & $5.7 \pm 0.47$ & $5.9 \pm 0.76$ \\
\hline ADL & $2.4 \pm 0.37$ & $2.8 \pm 0.44$ & $2.8 \pm 0.40$ \\
\hline $\mathrm{NE}_{\mathrm{L}},{ }^{4} \mathrm{Mcal} / \mathrm{kg}$ & $1.67 \pm 0.05$ & $1.65 \pm 0.04$ & $1.64 \pm 0.04$ \\
\hline RUP, ${ }^{5} \%$ of CP & $22.5 \pm 3.08$ & $22.0 \pm 3.79$ & $21.4 \pm 2.46$ \\
\hline Digestible energy, Mcal/kg & $2.76 \pm 0.08$ & $2.81 \pm 0.08$ & $2.94 \pm 0.11$ \\
\hline \multicolumn{4}{|c|}{$\begin{array}{l}{ }^{1} \text { Contained 38\% total inverted sugars, 30\% crude fiber, and 5\% CP (Jefo Nutrition Inc., Saint-Hyacinthe, QC, } \\
\text { Canada). }\end{array}$} \\
\hline \multicolumn{4}{|c|}{${ }^{2}$ Calcium salts of palm FA (Church \& Dwight Co. Inc., Princeton, NJ). } \\
\hline \multicolumn{4}{|c|}{$\begin{array}{l}{ }^{3} \text { Contained } 43.28 \% \text { sodium bicarbonate, } 19.37 \% \text { dicalcium phosphate, } 11.59 \% \text { sodium chloride, } 8.14 \% \text { am- } \\
\text { monium phosphate, } 0.41 \% \text { calcium carbonate, } 6.18 \% \mathrm{Mg}, 3.49 \% \mathrm{~K}, 0.22 \% \mathrm{Ca}, 2.21 \% \mathrm{Na}, 0.45 \% \mathrm{Zn}, 0.38 \% \\
\mathrm{Mn}, 0.15 \% \mathrm{Cu}, 0.01 \% \mathrm{Co}, 0.01 \% \mathrm{I}, 0.01 \% \text { sodium selenite, } 0.82 \% \text { mineral oil, } 2.61 \% \text { canola meal, } 1,095 \mathrm{kIU} \text { of } \\
\text { vitamin } \mathrm{E} / \mathrm{kg}, 2,400 \mathrm{kIU} \text { of vitamin } \mathrm{A} / \mathrm{kg} \text {, and } 1,150 \mathrm{kIU} \text { of vitamin } \mathrm{D} / \mathrm{kg} \text {. }\end{array}$} \\
\hline \multicolumn{4}{|c|}{${ }^{4}$ Calculated according to Weiss et al. (1992). } \\
\hline${ }^{5}$ Estimated from 12 -h ruminal incubation. & & & \\
\hline
\end{tabular}

Three multiparous lactating Holstein cows (not included in the production study; $742.3 \pm 34.2 \mathrm{~kg}$ of BW) fitted with ruminal cannulas were used in a $3 \times 3$ Latin square experiment, which consisted of 3 periods with 14 $\mathrm{d}$ of diet adaptation and $7 \mathrm{~d}$ of data collection. Cows were housed in tie-stalls and had continuous access to water. Dietary treatments were the same as in the production study. Chromic oxide $\left(\mathrm{Cr}_{2} \mathrm{O}_{3}\right)$ was used as an external marker to estimate total fecal output. Gelatin capsules containing $10 \mathrm{~g}$ of $\mathrm{Cr}_{2} \mathrm{O}_{3}$ were inserted into the rumen of each cow twice daily in equal intervals starting on d 1 of data collection period. Samples of rumen fluid were collected from various parts of the rumen with a syringe screwed to a stainless steel tube ending with a fine metal mesh (RT Rumen Fluid Collection Tube; Bar Diamond Inc., Parma, ID) on d 3 of the data-collection period before the morning feeding $(0 \mathrm{~h})$ and at 2, 4, 6, 8, 10, and $12 \mathrm{~h}$ postfeeding and on d 4, rumen fluid samples were collected at 1, 3, 5, 7, 9, and $11 \mathrm{~h}$ postfeeding. Ruminal $\mathrm{pH}$ was measured immediately using an Accumet $\mathrm{pH}$ meter (Fisher Scientific, Montreal, QC, Canada). Following pH determination, two 50-mL rumen fluid samples were preserved by adding $5 \mathrm{~mL}$ of $25 \%$ metaphosphoric acid and $5 \mathrm{~mL}$ of $0.1 \mathrm{~N} \mathrm{HCl}$ to determine VFA and $\mathrm{NH}_{3}-\mathrm{N}$ concentra- tions, respectively. Samples were immediately frozen at $-20^{\circ} \mathrm{C}$ for later analysis. Grabbed fecal samples were collected 6 times daily during the last $2 \mathrm{~d}$ of each collection period. Samples were then dried at $60^{\circ} \mathrm{C}$ in a forced-air oven for $72 \mathrm{~h}$ and pooled by cow.

Subsamples $(500 \mathrm{~g})$ of feeds were dried in a forced-air oven at $60^{\circ} \mathrm{C}$ for $72 \mathrm{~h}$ and ground through a $1-\mathrm{mm}$ screen using a Wiley mill (Arthur H. Thomas Co., Philadelphia, PA). Ground feed samples were analyzed for DM, ash, and ether extract using standard procedures (AOAC, 1990). Neutral detergent fiber (Van Soest et al., 1991) and ADF (AOAC, 1990) concentrations were determined using an Ankom Fiber Analyzer (Ankom Technology Corp., Macedon, NY). Analysis of NDF was done without the inclusion of sodium sulfite and with the use of a heat-stable $\alpha$-amylase. Acid detergent lignin was measured according to the Association of Official Analytical Chemists (AOAC, 1990). Crude protein $(\mathrm{N} \times 6.25)$ was measured using a Leco nitrogen analyzer (TruSpec Nitrogen Determinator System; Leco Corp., St Joseph, MI). Soluble crude protein and NPN concentrations were determined according to Licitra et al. (1996), whereas acid and neutral detergent-insoluble protein were measured by analyzing $\mathrm{ADF}$ and NDF residues, respectively, for total N. Starch content was 
determined colorimetrically according to McCleary et al. (1997).

Ground fecal samples were analyzed for DM, ash, $\mathrm{CP}$, and NDF as previously described. Milk samples were analyzed for fat, protein, lactose, and MUN using an infrared analyzer (MilkoScan, model Foss 4000; Foss Food Technology, Hillerød, Denmark). Milk TS content was determined according to the Association of Official Analytical Chemists (AOAC, 1990). Samples (15 $\mu \mathrm{L})$ of ruminal fluid preserved for VFA analysis were centrifuged at $11,000 \times g$ for $15 \mathrm{~min}$ at $4^{\circ} \mathrm{C}$ and analyzed for acetic, propionic, and butyric acids using HPLC (Andersson and Hedlund, 1983). The HPLC system included a Milton Roy 711 pump (Milton Roy UK Ltd., Sunderland, UK), a Valco CV-6-UHP injection valve (Valco Instruments Co. Inc., Houston, TX), an R 401 differential refractometer (Waters Corp., Milford, MA), and a $300 \times 7.8-\mathrm{mm}$ stainless steel column, packed with Aminex HPX-87 (Bio-Rad Laboratories Inc., Hercules, $\mathrm{CA})$. The conditions for the HPLC analysis were mobile phase $\left(0.013 \mathrm{M} \mathrm{H}_{2} \mathrm{SO}_{4}\right)$ and flow rate $(0.6 \mathrm{~mL} /$ min). Ruminal $\mathrm{NH}_{3}-\mathrm{N}$ concentration was determined colorimetrically with a multichannel Lachat Autoanalyzer (Lachat Instruments, Milwaukee, WI).

Data on the production study and total-tract nutrient utilization were analyzed as a Latin square design using PROC MIXED of SAS (SAS Institute, 1989) with the following model:

$$
\mathrm{Y}_{\mathrm{ijkh}}=\mu+\operatorname{trt}_{\mathrm{i}}+\text { block }_{\mathrm{j}}+\text { animal }_{\mathrm{jk}}+\text { per }_{\mathrm{h}}+\mathrm{e}_{\mathrm{ijkh}},
$$

where $Y_{\mathrm{ijkh}}$ represents the observation for dependent variables, $\mu$ is the overall mean, trt $_{i}$ is the fixed effect of the ith treatment, block $\mathrm{j}_{\mathrm{j}}$ is the fixed effect of the jth block, animal $\mathrm{j}_{\mathrm{jk}}$ is the random effect of the kth animal on the jth block, per $_{\mathrm{h}}$ is the fixed effect of the hth period, and $e_{i j k h}$ is the random residual error. Significant effects were considered detected at $P<0.05$.

Data on ruminal fermentation parameters were analyzed as repeated measures in time using PROC MIXED of SAS (SAS Institute, 1989) as follows:

$$
\begin{aligned}
\mathrm{Y}_{\mathrm{ijkh}}=\mu & +\operatorname{trt}_{\mathrm{i}}+\operatorname{animal}_{\mathrm{ij}}+\text { per }_{\mathrm{k}}+\text { time }_{\mathrm{h}} \\
& +\operatorname{trt}_{\mathrm{i}} \times \text { time }_{\mathrm{h}}+\mathrm{e}_{\mathrm{ijkh}},
\end{aligned}
$$

where $Y_{\mathrm{ijkh}}$ represents the observations for dependent variables, $\mu$ is the overall mean, trt $_{i}$ is the fixed effect of the ith treatment, animal $\mathrm{i}_{\mathrm{ij}}$ is the random effect of the jth cow on the ith treatment, per $_{\mathrm{k}}$ is the fixed effect of the kth period, time $_{\mathrm{h}}$ is the fixed effect of the hth time, $\operatorname{trt}_{\mathrm{i}} \times \mathrm{time}_{\mathrm{h}}$ is the fixed effect of the interaction between the ith treatment and the hth time, and $\mathrm{e}_{\mathrm{ijkh}}$ is the random residual error. Significant effects were declared at $P<0.05$. Orthogonal contrasts were used to test for linear and quadratic effects of adding dried molasses to the diet.

Intakes of DM, NDF, and CP were not influenced by dietary treatments (Table 2). Martel et al. (2011) found no effect of dietary molasses (up to $5 \%$ of the diet DM) on DMI of lactating cows, which agrees with our findings. Similarly, Morales et al. (1989) found no effect of cane molasses (up to $8 \%$ of diet DM) on DMI of lactating cows fed $60 \%$ alfalfa haylage. Broderick and Radloff (2004) reported that feeding a diet containing $3 \%$ liquid molasses improved DMI of lactating cows, whereas feeding a diet with $4 \%$ dried molasses had no effect.

Milk yield was not influenced by dietary treatments and averaged $32.9 \mathrm{~kg} / \mathrm{d}$ (Table 2). The effect of molasses on milk yield of dairy cows is inconsistent. Martel et al. (2011) reported that dietary molasses (up to 5\% of the diet DM) decreased milk yield and milk protein yield. Feeding dietary molasses with alfalfa silage-based diets up to $8 \%$ of the diet DM had no effect on milk and protein yields (Broderick and Radloff, 2004). However, both traits were adversely affected by a higher inclusion level. Added molasses reduced milk yield with $35 \%$ alfalfa haylage diet, but no effect was observed with $65 \%$ alfalfa haylage diet (Morales et al., 1989). However, milk protein concentration and yield linearly declined with molasses feeding, suggesting that MP supply may have limited milk protein synthesis as a result of molasses supplementation.

Milk urea nitrogen was linearly increased $(P<0.05)$ as the level of dried molasses increased (Table 2). The higher NPN content for the molasses-supplemented diets relative to the control diet (Table 1) may explain the differences observed in MUN in the current study. Factors influencing MUN include CP intake, percentage of ruminal degradable and undegradable protein, and dietary protein:energy ratio (Nousiainen et al., 2004).

Our results suggest that inclusion of dried molasses in dairy cow diets may have adverse effects on animal performance, as indicated by increased MUN concentration. In accordance with our findings, Broderick et al. (2002) reported that feeding a source of RUP, such as extruded soybean meal, improved milk production of lactating cows fed a high-alfalfa silage diet with NPN supplying $56 \%$ of dietary CP. Results of the current study demonstrate clear differences in microbial growth and fermentation rates between dry molasses and corn starch.

In the current study, dried molasses replaced highmoisture corn as the energy source. It has been suggested that molasses contain less energy due to its high ash content (i.e., $15 \%$ of the DM) and lack of hexose polymers. This may explain some of the adverse effects 
Table 2. Effects of molasses supplementation on performance of lactating cows fed high-alfalfa silage diets

\begin{tabular}{|c|c|c|c|c|c|c|c|}
\hline Item & \multicolumn{3}{|c|}{ Dietary treatment } & SEM & $P$-value & \multicolumn{2}{|c|}{$P$-value ${ }^{1}$} \\
\hline \multicolumn{8}{|l|}{ Intake } \\
\hline $\mathrm{DM}, \%$ of $\mathrm{BW}$ & 3.33 & 3.41 & 3.29 & 0.14 & 0.15 & 0.88 & 0.56 \\
\hline $\mathrm{NDF}, \mathrm{kg} / \mathrm{d}$ & 7.28 & 7.55 & 7.33 & 0.23 & 0.067 & 0.89 & 0.44 \\
\hline NDF, $\%$ of BW & 1.05 & 1.08 & 1.05 & 0.04 & 0.095 & 0.95 & 0.53 \\
\hline Milk & 33.88 & 32.77 & 32.27 & 1.44 & 0.020 & 0.38 & 0.85 \\
\hline ECM & 36.27 & 34.93 & 35.03 & 1.65 & 0.053 & 0.50 & 0.65 \\
\hline $4 \% \mathrm{FCM}$ & 34.50 & 33.28 & 33.53 & 1.70 & 0.13 & 0.61 & 0.66 \\
\hline SCM & 33.78 & 32.64 & 32.86 & 1.56 & 0.11 & 0.60 & 0.65 \\
\hline Fat & 1.40 & 1.34 & 1.38 & 0.08 & 0.26 & 0.78 & 0.56 \\
\hline Protein & 1.04 & 1.01 & 0.98 & 0.04 & 0.030 & 0.22 & 0.92 \\
\hline Fat & 4.15 & 4.12 & 4.28 & 0.14 & 0.29 & 0.52 & 0.60 \\
\hline Protein & 3.08 & 3.06 & 3.05 & 0.07 & 0.18 & 0.72 & 0.93 \\
\hline Lactose & 4.61 & 4.64 & 4.62 & 0.06 & 0.60 & 0.84 & 0.67 \\
\hline $\mathrm{TS}$ & 12.78 & 12.77 & 12.96 & 0.17 & 0.22 & 0.52 & 0.66 \\
\hline SNF & 8.64 & 8.65 & 8.69 & 0.08 & 0.68 & 0.72 & 0.93 \\
\hline MUN, mg/dL & 13.91 & 15.47 & 15.67 & 0.59 & $<0.0001$ & 0.015 & 0.26 \\
\hline
\end{tabular}

${ }^{1} \mathrm{~L}=$ linear; $\mathrm{Q}=$ quadratic.

${ }^{2}$ Milk/DMI.

on production parameters observed with the $6 \%$ molasses diet.

Molasses had no effect on apparent total-tract DM, $\mathrm{CP}, \mathrm{NDF}$, or gross energy digestibility (Table 3). Oelker et al. (2009) reported similar effect of molasses on DM, $\mathrm{NDF}$, and CP digestibility with alfalfa hay as a forage source. With the exception of improved NDF digestibility, feeding molasses up to $6 \%$ of the diet DM had no effect on total-tract nutrient utilization of lactating cows fed alfalfa silage-based diets (Broderick and Radloff, 2004).

Ruminal $\mathrm{pH}, \mathrm{NH}_{3}-\mathrm{N}$, and total VFA were not influenced by dietary treatments (Table 3 ). Feeding molasses with high-forage diets usually had no major effect on ruminal $\mathrm{pH}$ or total VFA concentrations (Broderick and Radloff, 2004; Oelker et al., 2009). The molar

Table 3. Effects of molasses supplementation on ruminal fermentation and apparent nutrient digestibility of lactating cows fed high-alfalfa silage diets

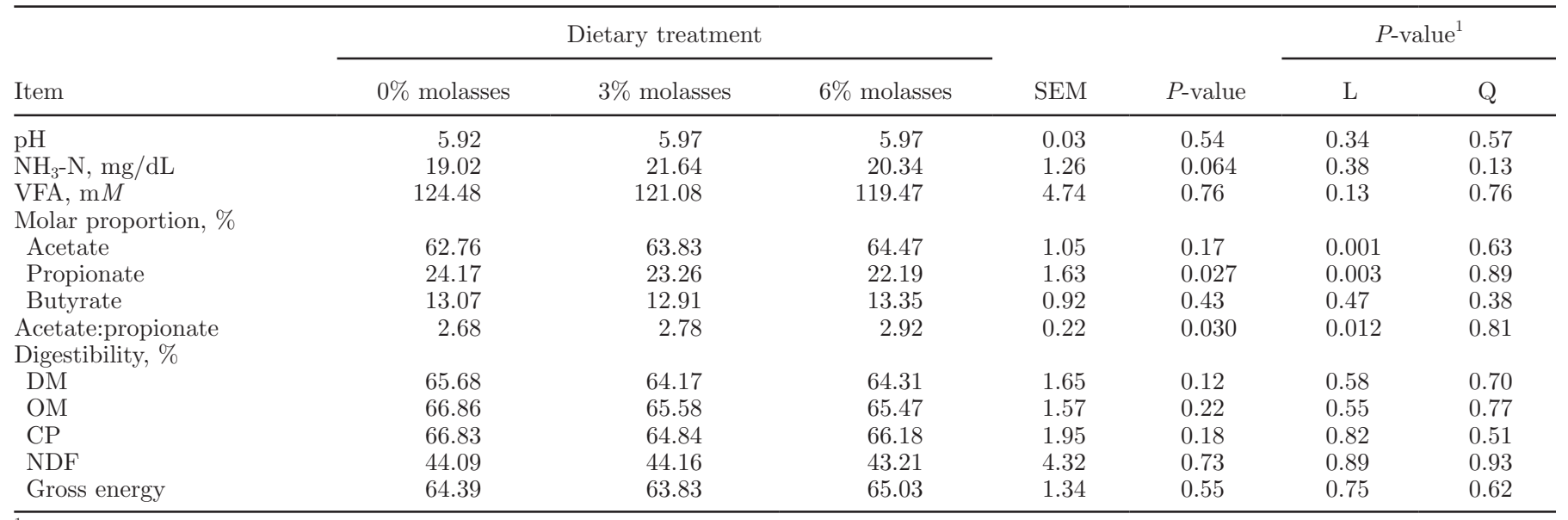

${ }^{1} \mathrm{~L}=$ linear; $\mathrm{Q}=$ quadratic. 
proportion of acetate linearly increased $(P<0.05)$, whereas the molar proportion of propionate linearly $(P$ $<0.05)$ decreased as the level of dried molasses increased (Table 3). Consequently, the acetate:propionate ratio linearly increased $(P<0.05)$ as the level of dried molasses increased. The higher molar proportion of propionate for the cows fed the control diet is likely due to the greater starch content for the control diet relative to the other 2 diets.

Inclusion of dried molasses failed to improve the performance of lactating dairy cows fed high-alfalfa silage diets. Furthermore, both levels of dietary molasses resulted in a significant increase in MUN concentration. This can be attributed to the higher soluble protein and lower energy content of molasses relative to highmoisture corn.

\section{ACKNOWLEDGMENTS}

The authors thank Gabrielle Guitard (Valacta, QC, Canada) for technical support and N. Gentesse (Bélisle Solution \& Nutrition Inc., Saint-Mathias sur Richelieu, QC, Canada) for diet formulation.

\section{REFERENCES}

Andersson, R., and B. Hedlund. 1983. HPLC analysis of organic acids in lactic acid fermented vegetables. Z. Lebensm. Unters. Forsch. 176:440-443.

AOAC (Association of Official Analytical Chemists). 1990. Official Methods of Analysis. 15th ed. Vol. 1. AOAC, Arlington, VA.
Broderick, G. A. 1995. Performance of lactating dairy cows fed either alfalfa silage or alfalfa hay as the sole forage. J. Dairy Sci. 78:320-329.

Broderick, G. A., D. R. Mertens, and R. Simons. 2002. Efficacy of carbohydrate sources for milk production by cows fed diets based on alfalfa silage. J. Dairy Sci. 85:1767-1776.

Broderick, G. A., and W. J. Radloff. 2004. Effects of molasses supplementation on the production of lactating dairy cows fed diets based on alfalfa and corn silage. J. Dairy Sci. 87:2997-3009.

Licitra, G., T. M. Hernandez, and P. J. Van Soest. 1996. Standardization procedures for nitrogen fractionation of ruminant feeds. Anim. Feed Sci. Technol. 57:347-358.

Martel, C. A., E. C. Titgemeyer, L. K. Mamedova, and B. J. Bradford. 2011. Dietary molasses increases ruminal $\mathrm{pH}$ and enhances ruminal biohydrogenation during milk fat depression. J. Dairy Sci. 94:3995-4004.

McCleary, B. V., T. S. Gibson, and D. C. Mugford. 1997. Measurement of total starch in cereal products by amyloglucosidase- $\alpha$ amylase method: Collaborative study. J. AOAC Int. 80:571-579.

Morales, J. L., H. H. Van Horn, and J. E. Moore. 1989. Dietary interaction of cane molasses with source of roughage: Intake and lactation effects. J. Dairy Sci. 72:2331-2338.

Nousiainen, J., K. J. Shingfield, and P. Huhtanen. 2004. Evaluation of milk urea nitrogen as a diagnostic of protein feeding. J. Dairy Sci. 87:386-398.

NRC. 2001. Nutrient Requirements of Dairy Cattle. 7th rev. ed. National Academy Press, Washington, DC.

Oelker, E. R., C. Reveneau, and J. L. Firkins. 2009. Interaction of molasses and monensin in alfalfa hay- or corn silage-based diets on rumen fermentation, total tract digestibility, and milk production by Holstein cows. J. Dairy Sci. 92:270-285.

SAS Institute. 1989. SAS User's Guide: Statistics. SAS Inst. Inc., Cary, NC.

Van Soest, P. J., J. B. Robertson, and B. A. Lewis. 1991. Methods for dietary fiber, neutral detergent fiber, and nonstarch polysaccharides in relation to animal nutrition. J. Dairy Sci. 74:3583-3597.

Weiss, W. P., H. R. Conrad, and N. R. St. Pierre. 1992. A theoretically-based model for predicting total digestible nutrient values of forages and concentrates. Anim. Feed Sci. Technol. 39:95-110. 